\title{
Simulation of delayed gamma rays from neutron- induced fissions using MCNP 6.1
}

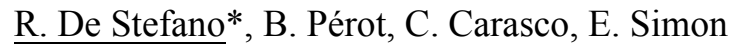 \\ * Nuclear Measurements Laboratory \\ roberto.destefano@cea.fr
}

\begin{abstract}
As part of its R\&D activities in the fields of radioactive waste drum storage and homeland security, the Nuclear Measurement Laboratory of CEA Cadarache has started studies related to the detection of induced delayed fission gamma rays as a signature of $U / P u$ presence either in radioactive wastes or in cargo containers and luggage. The study described in the present paper explores the feasibility of detecting fission delayed gamma rays of nuclear materials interrogated by a pulsed neutron generator. For this purpose, Monte Carlo simulations have been performed with ACT, the MNCP6 Activation Control Card. Simulated results have been compared with experimental data to validate the numerical model. Samples of uranium and plutonium have been irradiated for 2 hours with a pulsed D-T neutron generator delivering $14 \mathrm{MeV}$ neutrons with an average emission of $8.10^{7} \mathrm{n} / \mathrm{s}$, which are thermalised in a graphite cell called REGAIN. At the end of irradiation, activated nuclear materials were placed in a low-background, high-resolution gamma spectroscopy station in order to detect delayed gamma rays emitted by fission products. Anomalies have been observed in the calculated time decay curve of fission delayed gamma rays with MCNP6 ACT card, but the time behavior is correct for nonfission activated materials like aluminum or copper. On the other hand, the number of counts recorded in the main simulated gamma ray lines from activated nuclear material fission products is consistent with the experimental results, thus validating the simulation scheme in view of further studies on the characterization of radioactive waste drums or special nuclear material detection in cargo containers.
\end{abstract}

\section{INTRODUCTION}

Delayed gamma rays detection emitted after neutron-induced fission or photo-fission is being studied in the fields of radioactive waste drum characterization but also for homeland security [1] [2] [3] [4]. Indeed, the detection of well-known delayed gamma rays emitted by uranium and plutonium fission fragments can be a signature of nuclear materials presence either in legacy drums or in cargo containers. In addition, the relative intensities of these delayed gamma rays provide additional information on the nature of the interrogated isotopes, such as ${ }^{235} \mathrm{U}$ and ${ }^{239} \mathrm{Pu}$, which have different fission yields [5]. In this context, it is important to test and qualify simulation tools in view to further design nondestructive measurement systems based on the detection of induced-fission delayed gamma rays.

Manuscript submitted on June 4, 2019. This work takes place in the framework of Grenoble Institute of Technology, Physics, Electronics and Materials engineering cursus partnership with CEA Cadarache.

Roberto De Stefano, Bertrand Pérot, Cédric Carasco, Eric Simon are with CEA, DEN, Cadarache, DTN, SMTA, Nuclear Measurement Laboratory, F13108 Saint-Paul-Lez-Durance, France.
With the implementation of the new Activation Control Card (ACT Card) [6], evolution calculations are now possible with MCNP 6.1 and higher versions allowing the creation and transport of delayed particles from non-nuclear materials and fissionable isotopes. The study presented in this paper mainly focuses on the detection of delayed gamma rays emitted by fission fragments of nuclear materials $\left({ }^{235} \mathrm{U}\right.$ and $\left.{ }^{239} \mathrm{Pu}\right)$ or by non-nuclear materials activated during neutron irradiation. The creation of delayed gamma rays from fissionable isotopes is done with the option FISSION=P, and for non-nuclear materials with the option NONFISSION $=P$. In order not to calculate delayed gamma rays, the options to be used are FISSION=NONE for nuclear materials, and NONFISSION=NONE for non-nuclear materials. The main delayed gamma rays of interest for nuclear materials in this study based on LARA nuclear database [7] are reported in Tab. 1.

\begin{tabular}{lcccccc}
\hline $\begin{array}{l}\gamma \text { ray } \\
\text { energy }\end{array}$ & $\begin{array}{c}885 \\
\mathrm{keV}\end{array}$ & $\begin{array}{c}1011 \\
\mathrm{keV}\end{array}$ & $\begin{array}{c}1384 \\
\mathrm{keV}\end{array}$ & $\begin{array}{c}1436 \\
\mathrm{keV}\end{array}$ & $\begin{array}{c}1768 \\
\mathrm{keV}\end{array}$ & $\begin{array}{c}2218 \\
\mathrm{keV}\end{array}$ \\
\hline $\begin{array}{l}\text { Fission } \\
\text { fragment }\end{array}$ & ${ }^{104 \mathrm{Tc}}$ & ${ }^{101 \mathrm{Mo}}$ & ${ }^{92} \mathrm{Sr}$ & ${ }^{138} \mathrm{Cs}$ & ${ }^{138 \mathrm{Xe}}$ & ${ }^{138} \mathrm{Cs}$ \\
$\begin{array}{l}\text { Half-life } \\
\mathrm{T}_{1 / 2}\end{array}$ & $\begin{array}{c}18.3 \\
\mathrm{~min}\end{array}$ & $\begin{array}{c}14.61 \\
\mathrm{~min}\end{array}$ & $\begin{array}{c}2.65 \\
\mathrm{~h}\end{array}$ & $\begin{array}{c}33.4 \\
\mathrm{~min}\end{array}$ & $\begin{array}{c}14.14 \\
\mathrm{~min}\end{array}$ & $\begin{array}{c}33.4 \\
\mathrm{~min}\end{array}$ \\
\hline
\end{tabular}

Table 1: Main uranium and plutonium delayed gamma rays of interest

The $1778 \mathrm{keV}$ delayed gamma ray emitted by ${ }^{28} \mathrm{Al}$ $\left(\mathrm{T}_{1 / 2}=2.24 \mathrm{~min}\right)$ and the $1345 \mathrm{keV}$ line from ${ }^{64} \mathrm{Cu}$ $\left(\mathrm{T}_{1 / 2}=12.7 \mathrm{~h}\right)$ are also studied, which are produced by neutron radiative capture on ${ }^{27} \mathrm{Al}$ and ${ }^{63} \mathrm{Cu}$, respectively.

The simulation results obtained for these delayed gamma rays were confronted to experimental data in order to validate a calculation scheme adapted to further feasibility studies related to delayed gamma-ray measurements after neutron irradiation.

\section{EXPERIMENT}

The experimental campaign described in [5] is used to validate the calculation scheme based on MCNP 6.1 ACT card. Highly Enriched Uranium (HEU) and plutonium samples have been irradiated for 2 hours in a graphite cell named REGAIN (see Fig. 1 and Fig. 3). REGAIN was equipped with a pulsed D-T neutron generator (GENIE 16 model from SODERN) delivering $14 \mathrm{MeV}$ neutrons with an average emission of $8.10^{7} \mathrm{~s}^{-1}$, and with a coaxial N-type HPGe detector (from CANBERRA) of $33 \%$ relative efficiency inserted in 
one of the graphite walls. REGAIN was dedicated to PGNAA (Prompt Gamma Neutron Activation Analysis) studies, for instance to characterize toxic chemicals in radioactive waste drums [2] by detecting prompt gamma rays during (inelastic scattering) or between (radiative capture) the pulses of the neutron generator, as well as post-irradiation delayed gamma rays. For the experiments reported in [5], the pulse width was $10 \mathrm{~ms}$ and the pulse frequency $20 \mathrm{~Hz}$, i.e. $50 \mathrm{~ms}$ between pulses. The delayed gamma rays emitted by ${ }^{235} \mathrm{U}$ and ${ }^{239} \mathrm{Pu}$ fission fragments with half-lifes shorter than $10 \mathrm{~min}$ were measured between the neutron pulses. However, in this paper, we only focused on post-irradiation measurements of delayed gamma rays with half-lifes longer than $10 \mathrm{~min}$, because of the non-physical ACT results presented in section III (see further Fig. 7). The samples were moved just after the $2 \mathrm{~h}$ irradiation into a low-background spectrometer (see Fig. 2) to limit the background due to non-fissionable material activation. One can note for instance the $1778 \mathrm{keV}$ gamma ray from aluminum frame bars of REGAIN cell (see Fig. 1 and Fig. 3). The sample transfer time from REGAIN to the low-background station was around $1 \mathrm{~min}$, then delayed gamma-ray spectra of the ${ }^{235} \mathrm{U}$ and ${ }^{239} \mathrm{Pu}$ samples were recorded during 24 hours. In order to verify the half-life associated to the different fission products, acquisition was segmented in one spectrum every $15 \mathrm{~min}$. The low-background spectrometer is made of thick lead walls covered by thin copper layers, and it holds a type-P HPGe coaxial detector with a $25 \%$ relative efficiency. A thin $3 \mathrm{~mm}$ lead shield was placed between the metallic nuclear material samples and the HPGe detector in order to limit the detection of low-energy gamma rays from ${ }^{241} \mathrm{Am}$. Both lead shield and fissile material samples were placed $12.5 \mathrm{~cm}$ from the surface of the detector.

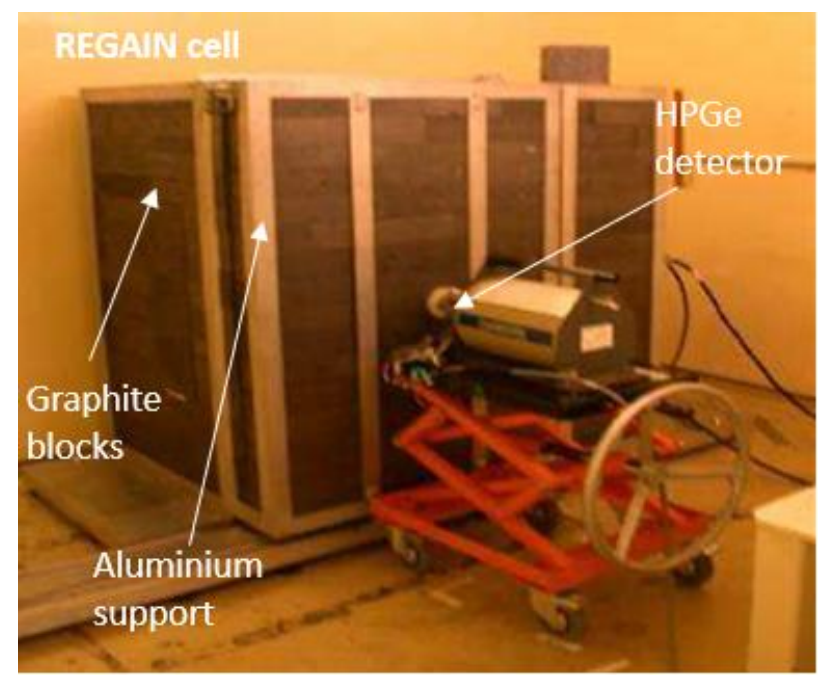

Figure 1: PGNAA REGAIN graphite cell

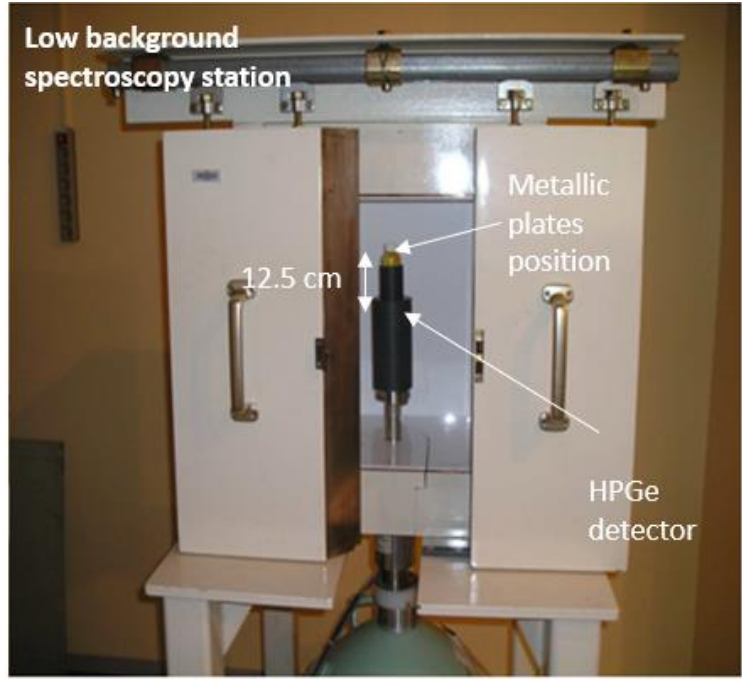

Figure 2: Low background spectroscopy station for induced-fission delayed gamma rays measurement

\section{SiMULATION VS. EXPERIMENT}

In order to validate the use of MCNP 6 ACT card, experimental and simulated results were confronted. Simulations were done based on REGAIN MCNP model presented in Fig. 3 and Fig. 4.

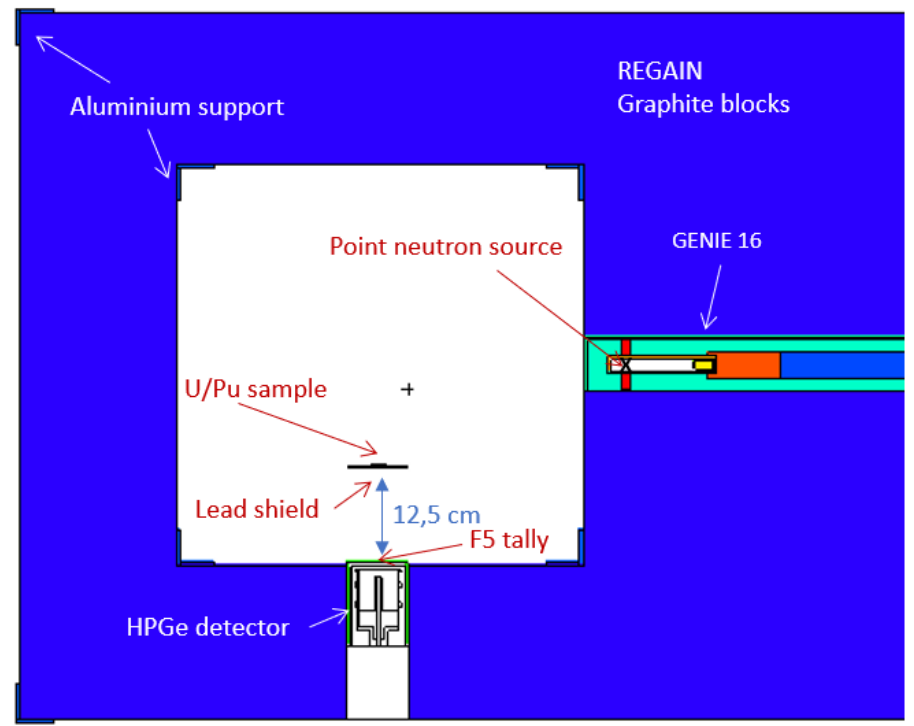

Figure 3: $X Y$ cross section representation of REGAIN cell MCNP model and cavity with the uranium and plutonium samples 


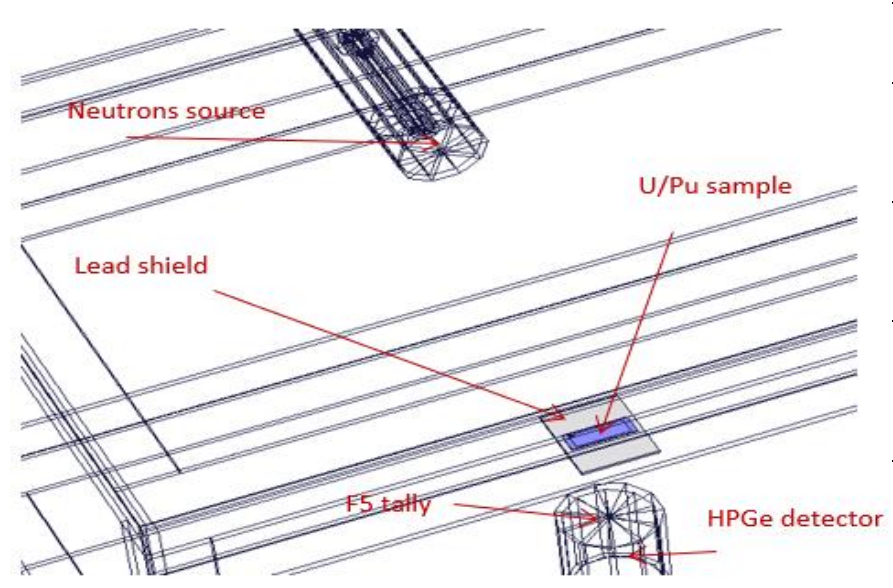

Figure 4: $3 D$ representation of REGAIN cell MCNP model and cavity with the uranium and plutonium samples.

In the MCNP model, the $14 \mathrm{MeV}$ neutrons are emitted in a point source located $10 \mathrm{~cm}$ away from the neutron generator endpoint. The graphite blocks are hold by aluminum frame bars with a total mass of $121 \mathrm{~kg}$ (note that depending on the information source, REGAIN being a legacy measurement system dismantled today, the mass of the aluminum bars ranges between 121 and $151 \mathrm{~kg}$ ). In order to simulate the sample transfer from REGAIN cell to the low-background spectrometer, the detection of delayed gamma rays emitted by the samples was calculated one minute after the end of the $2 \mathrm{~h}$ neutron irradiation. In order to simulate the low-background cell detection conditions, the fissile material samples and the $3 \mathrm{~mm}$ lead shield were placed $12.5 \mathrm{~cm}$ from the surface of the HPGe $33 \%$ relative efficiency detector, and activation gamma rays from not fissionable materials were not calculated by using the NONFISSION=NONE option of ACT card. The time binning used for delayed gamma ray calculation corresponds to a whole $24 \mathrm{~h}$ measurement with one spectrum recorded every $15 \mathrm{~min}$, as in the experiment.

For MCNP calculations, a F5:P point tally was placed on the surface of the detector, which allowed obtaining the full delayed gamma-ray spectra with the $33 \%$ relative efficiency HPGe detector response function implemented in MODAR software [9]. The response function of the $25 \% \mathrm{HPGe}$ detector used in the low-background spectrometer has not been parametrized with MODAR. Therefore, to calculate the signal expected for a $25 \% \mathrm{HPGe}$, the number of counts obtained with the MODAR 33\% relative efficiency HPGe is corrected by the ratio of full peak efficiency of the $25 \%$ HPGe over the full peak efficiency of the $33 \%$ HPGe for all delayed gamma rays of interest. This ratio, reported in Tab. 2, has been obtained by simulating mono-energetic photon point sources placed at a $12.5 \mathrm{~cm}$ distance from the top of both detectors for each delayed gamma ray of interest.

\begin{tabular}{lcccccc}
\hline $\begin{array}{l}\gamma \text { ray } \\
\text { energy }\end{array}$ & $\begin{array}{l}885 \\
\mathrm{keV}\end{array}$ & $\begin{array}{l}1011 \\
\mathrm{keV}\end{array}$ & $\begin{array}{l}1384 \\
\mathrm{keV}\end{array}$ & $\begin{array}{l}1436 \\
\mathrm{keV}\end{array}$ & $\begin{array}{l}1768 \\
\mathrm{keV}\end{array}$ & $\begin{array}{l}2218 \\
\mathrm{keV}\end{array}$ \\
\hline $\begin{array}{l}\text { Efficiency } \\
\text { for a 25\% } \\
\text { HPGe }\end{array}$ & $\begin{array}{l}1.471 \\
\times 10^{-3}\end{array}$ & $\begin{array}{l}1.334 \\
\times 10^{-3}\end{array}$ & $\begin{array}{l}1.014 \\
\times 10^{-3}\end{array}$ & $\begin{array}{l}0.982 \\
\times 10^{-3}\end{array}$ & $\begin{array}{l}0.820 \\
\times 10^{-3}\end{array}$ & $\begin{array}{l}6.582 \\
\times 10^{-4}\end{array}$ \\
\hline $\begin{array}{l}\text { Efficiency } \\
\text { for a 33\% }\end{array}$ & $\begin{array}{l}1.875 \\
\times 10^{-3}\end{array}$ & $\begin{array}{l}1.686 \\
\times 10^{-3}\end{array}$ & $\begin{array}{l}1.317 \\
\times 10^{-3}\end{array}$ & $\begin{array}{l}1.277 \\
\times 10^{-3}\end{array}$ & $\begin{array}{l}1.054 \\
\times 10^{-3}\end{array}$ & $\begin{array}{l}0.880 \\
\times 10^{-3}\end{array}$ \\
$\begin{array}{l}\text { HPGe } \\
\begin{array}{l}\text { Efficiency } \\
\text { ratio (25\% } \\
\text { to 33\%) }\end{array}\end{array}$ & 0.784 & 0.791 & 0.770 & 0.769 & 0.778 & 0.748 \\
\hline
\end{tabular}

Table 2: Ratios of the HPGe $25 \%$ and HPGe $33 \%$ detectors relative efficiencies calculated with MCNP

Simulated and experimental spectra are shown in Fig. 5 and Fig. 6 for uranium and plutonium samples, respectively.

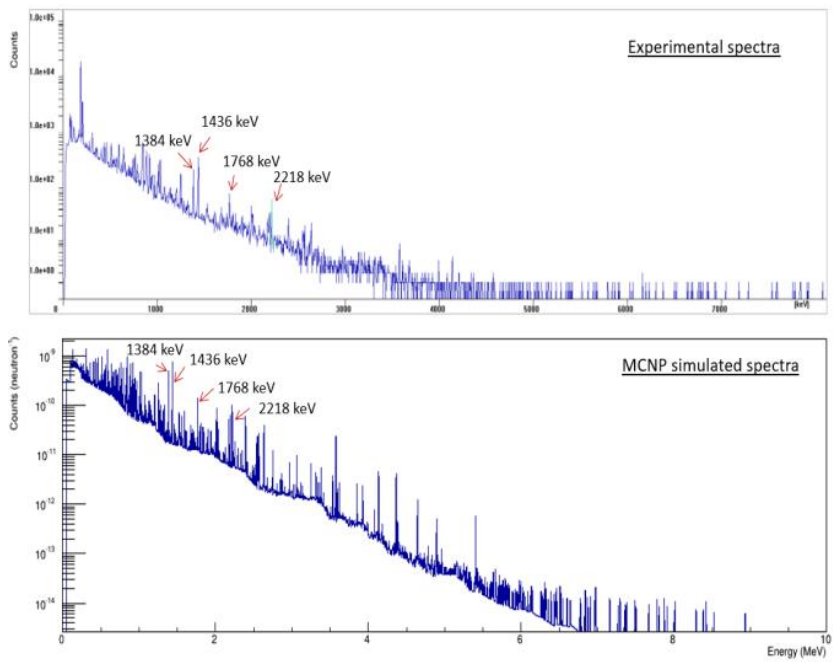

Figure 5: Experimental (above) and simulated (below) delayed gamma spectra for the first 15 min following the end of the uranium sample irradiation in REGAIN cell
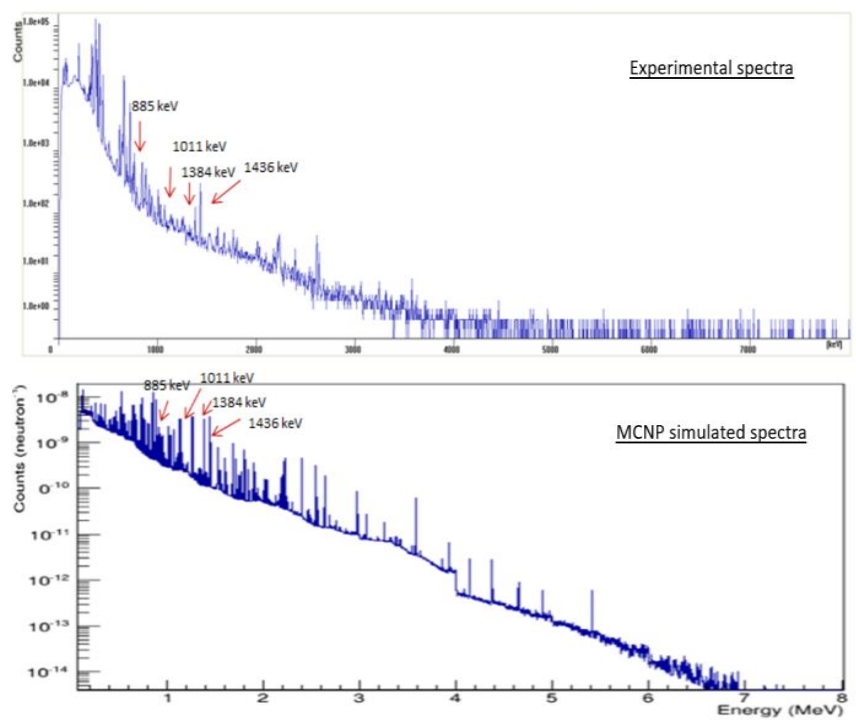

Figure 6: Experimental (above) and simulated (below) delayed gamma spectra for the first 15 min following the end of the plutonium sample irradiation in REGAIN cell 
Although a non-physical continuum is observed in the decay curves of the main delayed gamma rays of interest $12 \mathrm{~h}$ after the end of neutron irradiation (see Fig. 7), the first hours seem to be properly calculated and the first 15 min have been used in order to estimate the simulated net counts. The non-physical continuum was subtracted, as illustrated in Fig. 7 for the delayed gamma ray at $1384 \mathrm{keV}$ emitted by the uranium sample. Then the net area in the first $15 \mathrm{~min}$ after the end of irradiation was multiplied by the neutron generator emission $\left(8.10^{7} \mathrm{n} \cdot \mathrm{s}^{-1}\right)$, by the $2 \mathrm{~h}$ irradiation time and multiplied by the corrections factors reported in Tab. 2 for each delayed gamma ray of interest.
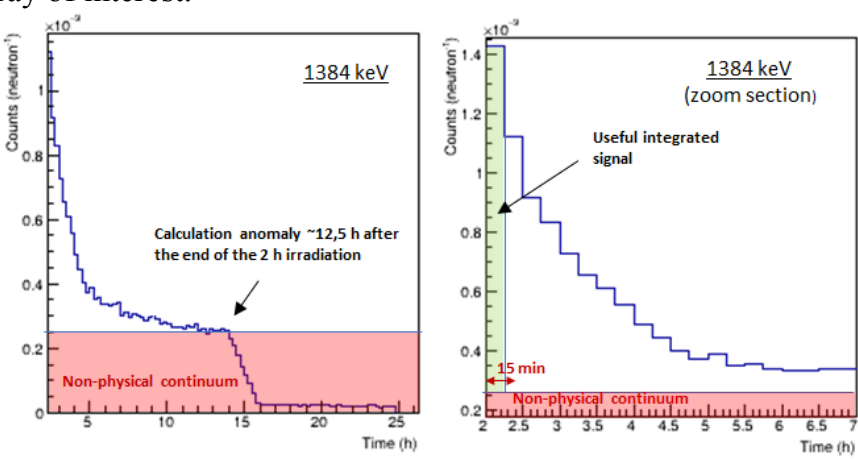

Figure 7: Simulated number of counts (per source neutron) as a function of time after the end of the $2 \mathrm{~h}$ irradiation, for the $1384 \mathrm{keV}$ delayed gamma ray of the ${ }^{235} \mathrm{U}$ sample, showing also the principle of the non-physical continuum (in red) subtraction from the signal of the first 15 min (in green)

Simulated and experimental net counts obtained for the main delayed gamma rays of ${ }^{235} \mathrm{U}$ and ${ }^{239} \mathrm{Pu}$ are shown in Tab.3.

\begin{tabular}{lcccccc}
\hline$\gamma$ ray energy & $\begin{array}{c}885 \\
\mathrm{keV}\end{array}$ & $\begin{array}{c}1011 \\
\mathrm{keV}\end{array}$ & $\begin{array}{c}1384 \\
\mathrm{keV}\end{array}$ & $\begin{array}{c}1436 \\
\mathrm{keV}\end{array}$ & $\begin{array}{c}1768 \\
\mathrm{keV}\end{array}$ & $\begin{array}{c}2218 \\
\mathrm{keV}\end{array}$ \\
\hline $\begin{array}{l}\text { Experimental } \\
\text { net counts } \\
\text { with U }\end{array}$ & $\begin{array}{c}790 \pm \\
67\end{array}$ & $\begin{array}{c}918 \pm \\
98\end{array}$ & $\begin{array}{c}612 \pm \\
40\end{array}$ & $\begin{array}{c}1211 \\
\pm 54\end{array}$ & $\begin{array}{c}172 \pm \\
25\end{array}$ & $\begin{array}{c}102 \pm \\
24\end{array}$ \\
\hline $\begin{array}{l}\text { MCNP 6.1 } \\
\text { net counts } \\
\text { with U }\end{array}$ & $\begin{array}{c}648 \pm \\
8\end{array}$ & $\begin{array}{c}744 \pm \\
23\end{array}$ & $\begin{array}{c}597 \pm \\
10\end{array}$ & $\begin{array}{c}877 \pm \\
12\end{array}$ & $\begin{array}{c}183 \pm \\
4\end{array}$ & $\begin{array}{c}130 \pm \\
3\end{array}$ \\
\hline $\begin{array}{l}\text { Experimental } \\
\text { net counts } \\
\text { with Pu }\end{array}$ & 1464 & $\begin{array}{c}760 \pm \\
66\end{array}$ & $\begin{array}{c}347 \pm \\
36\end{array}$ & $\begin{array}{c}1057 \\
\pm 48\end{array}$ & $\begin{array}{c}102 \pm \\
29\end{array}$ & $\begin{array}{c}198 \pm \\
37\end{array}$ \\
\hline $\begin{array}{l}\text { MCNP 6.1 } \\
\text { net counts }\end{array}$ & $873 \pm$ & $552 \pm$ & $238 \pm$ & $567 \pm$ & $118 \pm$ \\
with Pu & 6 & 14 & 3 & 4 & 2 & $85 \pm 1$ \\
\hline
\end{tabular}

Table 3: Simulated vs. experimental net counts of the main delayed gamma rays of interest from uranium and plutonium samples after a 15 min measurement following a $2 \mathrm{~h}$ irradiation in REGAIN neutron interrogation cell.

Uncertainties for experimental counts were calculated as $\sqrt{S+2 B}$, where $\mathrm{B}$ corresponds to the Compton background under the delayed gamma peak of interest and $S$ to the net peak area. In the case of simulated results, for which about $5.10^{9}$ source neutrons were computed, only the corresponding statistical uncertainties of around $1 \%$ are reported. However, as detailed in [5], the uranium and plutonium samples used for this study have important self-shielding factors of respectively 3.8 and 5.7, with a large uncertainty due to imprecise knowledge of the geometry of their fissile core. In addition, uncertainties related to delayed gamma ray nuclear data might also be significant. Taking into account these important sources of uncertainties, simulated and experimental net counts are quite consistent, thus validating the use of MCNP 6.1 Activation Control Card for predicting the order of magnitude of induced-fission delayed gamma ray signal.

The experiment vs. simulation comparison is also performed for the net counts of the $1778 \mathrm{keV}$ activation gamma ray due to the aluminum frame bars of REGAIN cell. The experimental net counts measured during a $30 \mathrm{~ms}$ gate between the pulses of the neutron generator for a whole $2 \mathrm{~h}$ neutron irradiation as presented in Fig. 8 are evaluated to $153937 \pm 443$ counts.

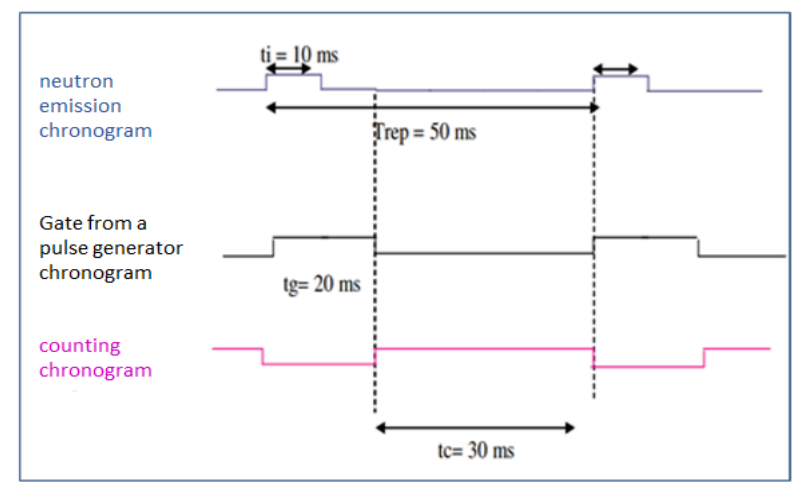

Figure 8: counting chronogram for the PGNAA experiment for the $1778 \mathrm{keV}$ total net counts evaluation

The aluminum support MCNP REGAIN model is presented in Fig. 9.

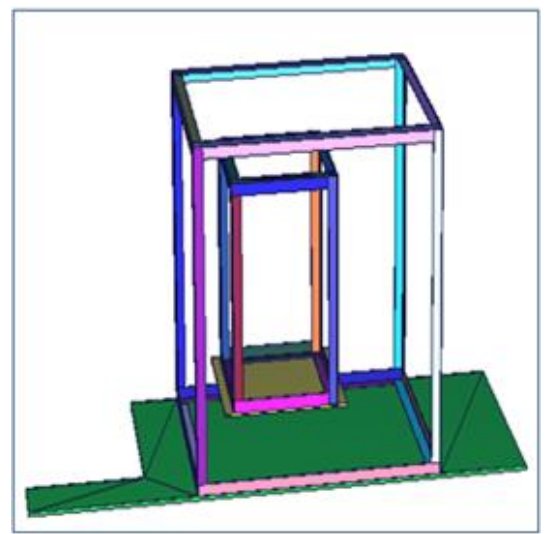

Figure 9: REGAIN aluminum support MCNP model (121 kg mass)

Contrary to delayed gamma rays from uranium and plutonium fission fragments, no anomaly is observed after the end of irradiation in the decay curve of the ${ }^{28} \mathrm{Al}\left(\mathrm{T}_{1 / 2}=\right.$ $2.24 \mathrm{~min}$ ) $1778 \mathrm{keV}$ activation gamma ray (see Fig. 12 in section V). Furthermore, the decay curve seems also properly calculated for longer half-life activation products such as the $1345 \mathrm{keV}$ activation gamma ray of ${ }^{64} \mathrm{Cu}\left(\mathrm{T}_{1 / 2}=12.7 \mathrm{~h}\right)$, see Fig. 12. 
The simulated net counts were calculated as the net area during the $2 \mathrm{~h}$ total neutron irradiation, multiplied by the $2 \mathrm{~h}$ irradiation time and the $8.10^{7} \mathrm{n} \cdot \mathrm{s}^{-1}$ average neutron generator emission, and finally normalized by a $3 / 5$ factor corresponding to the ratio of the $30 \mathrm{~ms}$ gate out of the $50 \mathrm{~ms}$ pulse repetition period (Fig. 8). Net simulated counts with this model are evaluated to $253038 \pm 227$ counts, which is twice the measured counts. Note that calculation uncertainty only corresponds to MCNP simulation statistical uncertainty, i.e. $0.09 \%$ here.

The over-estimation by MCNP calculation has probably several origins. A possible cause could be the simple MNCP model of the irradiation casemate where REGAIN was located (for instance a paraffin door that was modeled as concrete), as well as non-modelled objects and laboratory equipment located near REGAIN cell, which may have an important impact on the thermal neutron flux around REGAIN. Indeed, the largest aluminum mass comes from the external frame bars as shown in Fig. 1 and 9, in which the ${ }^{27} \mathrm{Al}(\mathrm{n}, \gamma)$ activation rate highly depends on the external thermal flux. It is also important to recall that the total aluminum mass is not known with a good precision (between 121 and $151 \mathrm{~kg}$ ). On the other hand, the badly known bore concentration of REGAIN graphite blocks, which varies at least from $4 \mathrm{ppm}$ to $16 \mathrm{ppm}$ according analyses of a few samples taken in REGAIN, might also be a significant cause of calculation over-estimation. Indeed, modelling the whole REGAIN graphite blocks with $16 \mathrm{ppm}$ bore concentration rather than $4 \mathrm{ppm}$ decreases the simulated $1778 \mathrm{keV}$ signal from $253038 \pm 227$ counts to $208457 \pm 833$ counts. As previously, only MCNP statistical fluctuations are reported in these results, which are of the order of $0.09 \%$ and $0.4 \%$ for each computation, respectively.

Taking into account these possible causes of biases in the calculation, the MCNP activation control card provides an order of magnitude of the activation signal of aluminum.

\section{COMPLEMENTARY ACT CALCULATION TESTS}

In order to better understand the anomaly observed $12 \mathrm{~h}$ after the end of irradiation in the delayed gamma rays decay curves (Fig. 7), we performed complementary calculations with a simpler geometry of nuclear and non-nuclear materials.

As calculations with ACT card demand an important computation time (several days with a cluster of few hundred cores for the study presented in former section), a simpler geometry corresponding to a spherical sample with a point source emitting $0.025 \mathrm{eV}$ thermal neutrons in its center has been modeled, as presented in Fig. 10. All source neutrons are emitted at time zero.

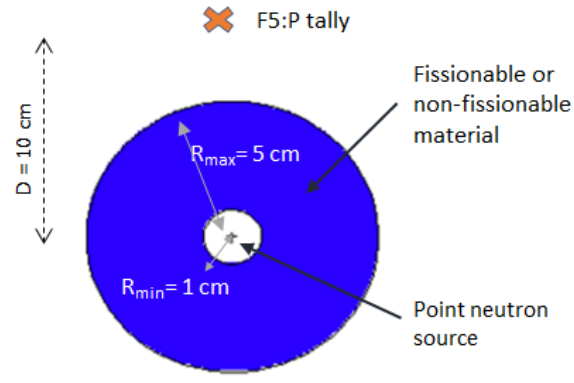

Figure 10: MCNP model for the study of delayed gamma rays and activation gamma rays created with ACT card

The first step of this study concerns the main delayed gamma rays of interest induced in a ${ }^{235} \mathrm{U}$ or a ${ }^{239} \mathrm{Pu}$ sphere. As for the previous study of section III with a $2 \mathrm{~h}$ neutron irradiation in REGAIN cell, the calculated decay curve for a theoretical neutron irradiation peak at time zero presents several anomalies, see Fig. 11. The most visible anomaly corresponds to a spectra discontinuity about $10.5 \mathrm{~h}$ after the irradiation peak, which might correspond to the $2 \mathrm{~h}$ long nonphysical decay observed in Fig. 7 between $12 \mathrm{~h}$ and $14 \mathrm{~h}$ approximately, after the $2 \mathrm{~h}$ irradiation. Fig. 11 shows the decay of the $1384 \mathrm{keV}$ and $1436 \mathrm{keV}$ delayed gamma rays of ${ }^{235} \mathrm{U}$ and ${ }^{239} \mathrm{Pu}$, which are also present in the curves of the other delayed gamma rays of interest emitted by uranium and plutonium fission fragments.
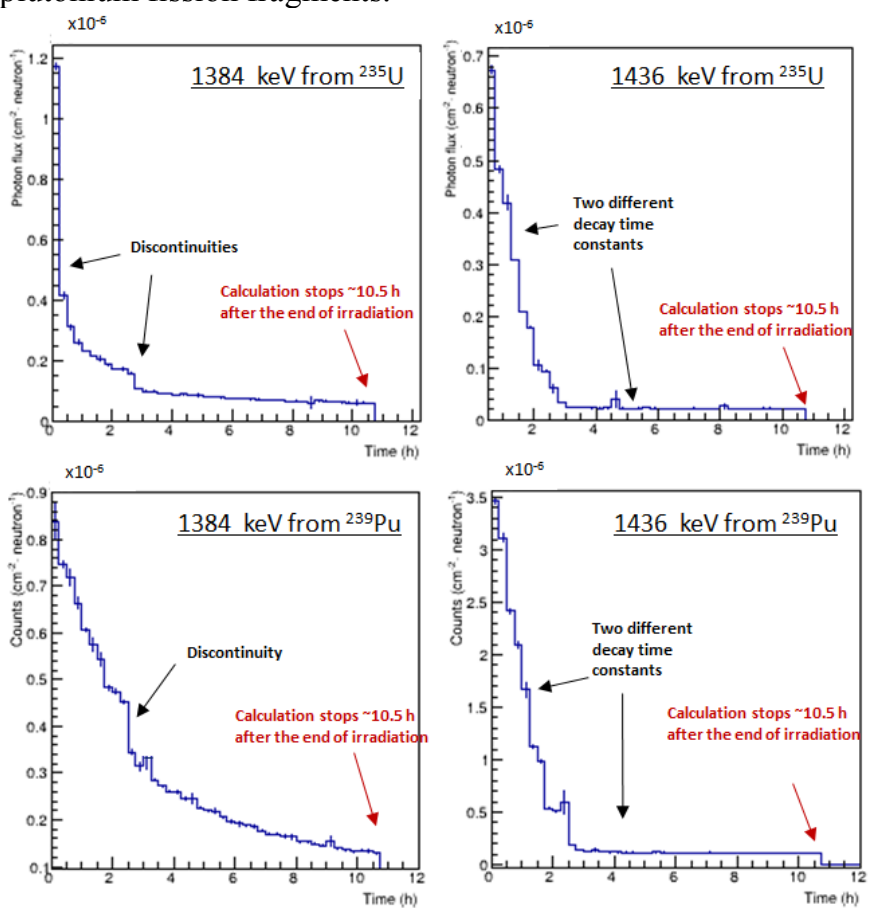

Figure 11: $1384 \mathrm{keV}$ and $1436 \mathrm{keV}$ delayed gamma rays from uranium (above) and plutonium (below) time decay curves

The same study with the spherical geometry of Fig. 10 has been done with aluminum and copper. As for the $2 \mathrm{~h}$ neutron irradiation in REGAIN, no calculation discontinuities are observed here in the $1778 \mathrm{keV}$ decay curve with a neutron emission peak at time zero, see Fig. 12 that also shows a normal decay for the $1345 \mathrm{keV}$ activation gamma ray of copper. The decay curves of the $1778 \mathrm{keV}$ activation gamma 
ray from ${ }^{28} \mathrm{Al}$ and $1345 \mathrm{keV}$ activation gamma ray from ${ }^{64} \mathrm{Cu}$ are presented in Fig. 12.
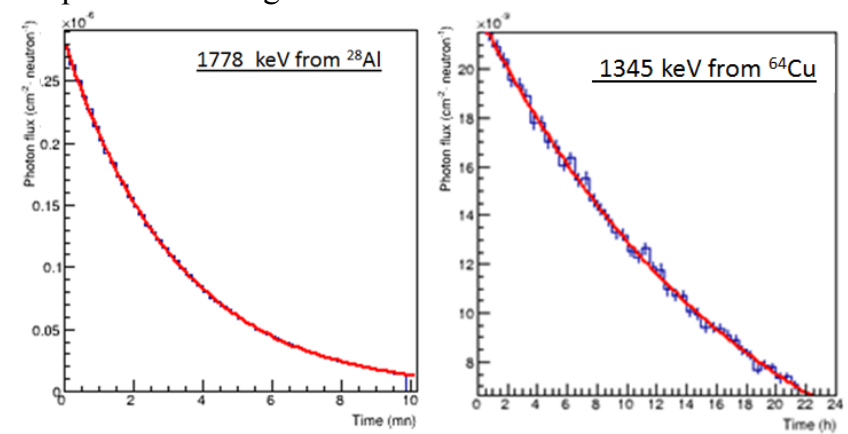

Figure 12: $1778 \mathrm{keV}$ (left) and $1345 \mathrm{keV}$ (right) activation gamma rays from aluminum and copper, respectively.

The exponential fits of the $1778 \mathrm{keV}$ and $1345 \mathrm{keV}$ decay curves gives ${ }^{28} \mathrm{Al}$ and ${ }^{64} \mathrm{Cu}$ half-lifes consistent with theoretical data from LARA nuclear database : $\mathrm{T}_{1 / 2}{ }^{\text {sim }}=2.24 \pm$ $0.006 \mathrm{~min}$ vs. $\mathrm{T}_{1 / 2}^{\text {th }}=2.2414(12) \mathrm{min}$ for aluminum, and $\mathrm{T}_{1 / 2}^{\text {sim }}=12.74 \pm 0.03 \mathrm{~h}$ vs. $\mathrm{T}_{1 / 2}^{\text {th }}=12.700(2) \mathrm{h}$ for copper.

\section{CONCLUSION}

The ACT card allowing evolution transport calculation in MCNP 6.1 was used to model neutron-induced fission delayed gamma rays, as well as activation gamma rays from nonfissionable materials. Although the decay curves of delayed gamma rays from nuclear materials show non-physical discontinuities, the simulated net counts are consistent with experiment for uranium and plutonium samples irradiated in REGAIN graphite cell. On the other hand, the decay curves of activation gamma rays from non-fissionable materials such as aluminum and copper show a more physical exponential shape with half-lifes consistent with ${ }^{28} \mathrm{Al}$ and ${ }^{64} \mathrm{Cu}$ ones.

Quantitatively, the number of counts predicted with MCNP 6 ACT card is consistent with experimental data, taking into account significant modeling uncertainties. Therefore, the calculation scheme presented in section III can be used to perform feasibility studies related to the measurement of delayed gamma rays from neutron induced fission in the fields of radioactive waste drum characterization as presented in [10], or for homeland security with the detection of special nuclear materials. The use of MCNP ACT card is also considered to model systems based on the detection of delayed gamma rays induced by photo-fission for radioactive waste drum characterization as presented in [11] [12].

\section{REFERENCES}

[1] M. Agelou et al., « Detecting special nuclear materials inside cargo containers using photofission », in Nuclear Science Symposium Conference Record (NSS/MIC), 2009 IEEE, 2009, p. 936-939.

[2] B. W. Blackburn et al., « Utilization of actively-induced, prompt radiation emission for nonproliferation applications », Nucl. Instrum. Methods Phys. Res. Sect. B
Beam Interact. Mater. At., vol. 261, n 1-2, p. 341-346, août 2007.

[3] J. Stevenson, T. Gozani, M. Elsalim, C. Condron, et C. Brown, « Linac based photofission inspection system employing novel detection concepts ", Nucl. Instrum. Methods Phys. Res. Sect. Accel. Spectrometers Detect. Assoc. Equip., vol. 652, no 1, p. 124-128, oct. 2011.

[4] M. Gmar et al., « Detection of nuclear material by photon activation inside cargo containers », présenté à Defense and Security Symposium, Orlando (Kissimmee), FL, 2006, p. 62130F.

[5] T. Nicol et al., « Feasibility study of $235 \mathrm{U}$ and $239 \mathrm{Pu}$ characterization in radioactive waste drums using neutron-induced fission delayed gamma rays $», \mathrm{Nucl}$. Instrum. Methods Phys. Res. Sect. Accel. Spectrometers Detect. Assoc. Equip., vol. 832, p. 85-94, oct. 2016.

[6] J. W. Durkee, « MCNP6 DELAYED-PARTICLE VERIFICATION AND VALIDATION Rev 5: January 26, $2012 »$, p. 54.

[7] « NUCLEIDE-LARA on the web (2018) ». [online]. available on : http://www.nucleide.org/Laraweb/index.php.

[8] J.L Ma, C. Carasco, B. Perot, E. Mauerhofer, J. Kettler, et A. Havenith, «Prompt gamma neutron activation analysis of toxic elements in radioactive waste packages », Appl Radiat Isot 702012 1216-1263.

[9] C. Carasco, «MCNP output data analysis with ROOT (MODAR) », Comput. Phys. Commun., vol. 181, n 12, p. 2210-2211, déc. 2010.

[10] R. De Stefano, B. Perot, C. Carasco, E. Simon, T. Nicol, et E. Mauerhofer, " Characterization of $870 \mathrm{~L}$ radioactive waste drums using delayed gamma rays from neutroninduced fissions "), vol. presented in the Seminar of Activation Analysis and Gamma Spectrometry SAAGAS27, submitted to the Journal of Radioanalytical and Nuclear Chemistry.

[11] E. Simon, F. Jallu, B. Pérot, et S. Plumeri, « Feasibility study of fissile mass quantification by photofission delayed gamma rays in radioactive waste packages using MCNPX », Nucl. Instrum. Methods Phys. Res. Sect. Accel. Spectrometers Detect. Assoc. Equip., vol. 840, p. 28-35, déc. 2016.

[12] E. Simon, F. Jallu, B. Perot, et S. Plumeri, « Fissile mass quantification in radioactive waste packages using photofission delayed gamma rays », in 2016 IEEE Nuclear Science Symposium, Medical Imaging Conference and Room-Temperature Semiconductor Detector Workshop (NSS/MIC/RTSD), Strasbourg, France, 2016, p. 1-4. 